the University of Edinburgh, then held by the aged James Gregory the second, the brother of David Gregory (1661-1708), once Savilian professor in the University of Oxford, and nephew of James Gregory (1638-75) of telescope fame, both of whom had held the same chair. It was in connexion with Maclaurin's candidature that Newton, then eightythree years of age, wrote to the Provost of Edinburgh, "I am glad to understand, that Mr. Maclaurin is in good repute amongst you for his skill in mathematics, for I think he deserves it very well. And to satisfy you that I do not flatter him, and also to encourage him to accept the place of assisting Mr. Gregory, in order to succeed him, I am ready, if you please to give me leave, to contribute $£ 20$ per annum towards a provision for him, till Mr. Gregory's place becomes void, if I live so long, and I will pay it to his Order in London."

In Edinburgh Maclaurin at once made his mark, being both a successful teacher and experimentalist. David Gregory had been the first to teach the Newtonian philosophy in Scotland, and Maclaurin devoted much of his time to the same subject. $\mathrm{He}$ was, however, a man of broad interests and practical outlook, and assisted both public bodies and private individuals in many ways. With his colleague Andrew Plummer, who held the chair of medicine and chemistry from 1726, he was very active in the medical society, which about 1739 became the Philosophical Society, the forerunner of the Royal Society of Edinburgh. Maclaurin's "Treatise on Fluxions", published in 1742, was most highly commended by Lagrange and was translated into French by Pezenas in 1749. To-day, however, he is remembered most for his work "An Account of Sir Isaac Newton's Philosophical Discoveries", published two years after his death by his pupil and friend Patrick Murdoch, for the benefit of Maclaurin's widow and children. An elder brother of Maclaurin became known as a preacher and controversialist, while his eldest son, John Maclaurin, rose to the Scottish bench and was created Lord Dreghorn. A sketch of Maclaurin's career was printed by Murdoch in the book on Newton's discoveries. Maclaurin has been referred to as "the one mathematician of first rank trained in Great Britain in the eighteenth eentury".

\section{A DARWIN LETTER}

$\mathrm{T}$ HE issue of the Transactions of the Kansas Academy of Science of December 1945 (vol. 48, No. 3) contains an editorial note and a copy of a letter from Charles Darwin, hitherto unpublished, which it seems probable was the last he wrote before he died. The original of this letter is now in the Library of Kansas University, presented by the son of the late Prof. J. E. Todd (of Iowa), to whom it was written on April 10, 1882, nine days before Charles Darwin's death.

As is pointed out in the editorial comment, Darwin had been suffering from heart attacks some months before, but with the spring he seemed to be rallying, and schemes for further experimental work filled his mind. Prof. Todd's article, which gave rise to the letter, appeared in the American Naturalist of April 1882, though it was read before the Biological Society of Washington in March 1881, and must soon have come to the notice of Charles Darwin after publication. The title runs: "On the flowers of Solanum Rostratum and Cassia Chamæcrista", and it deals with the asymmetrical arrangement of the reproductive organs, and in the case of Cassia, of the flower as well.

The detailed observations and the conclusion that such arrangements would encourage cross-fertilization within the species would have delighted Darwin, whose mind had been running on such similar lines. His delight in detailed contrivances and the puzzle of their evolutionary significance was still vividly active in his mind in his seventy-fourth year, and it is fitting that his last known scientific utterance should be on a botanical matter. For there was an evolutionary progression in his own researches. His first insight into science was attained through geology; he moved on to zoology, and thence to botany, with the thread of world evolution connecting each subject. Fifty years before this letter was written he knew practically nothing of botany, and the exigencies of geological and zoological observations and deductions during the voyage of the Beagle allowed him scant time to probe any further; yet there is one note on a specimen sent home which shows his discriminating sense of observation, even when backed by little or no knowledge: "The Cactus from Port Desire. The stamens when touched collapsed rapidly and with foree on the pistil; as also did the petals, but in a less sudden manner." Movements of stamens ; insect visits ; fertilization ; adaptation and heredity-the germ of interest here lay fallow that led many years later to the publication of six of his books, and to this last known letter written to Prof. J. E. Todd nine days before he died, and here quoted.

$\begin{array}{ll}\text { April } 101882 & \text { Down, } \\ & \text { Beckenham, Kent } \\ & \text { Railway Station } \\ & \text { Orpington. S.E.R. }\end{array}$

\section{Dear Sir}

I hope that you will excuse the liberty which as a stranger I take in begging a favor of you. I have read with unusual interest your very interesting paper in the American Naturalist on the structure of the flowers of Solanum rostratum, and I shd. be grateful if you would send me some seed in a small box (telling me whether the plant is an annual, so that I may know when to sow the seeds), in order that I may have the pleasure of seeing the flowers and experimenting on them. But if you intend to experiment on them, of course you will not send me the seeds, as I shd. be very unwilling to interfere in any way with your work. I shd. also rather like to look at flowers of Cassia chamaecrista.

Many years ago I tried some experiments in a remotely analogous case and this year am trying others. I described what I was doing to Dr. Fritz Müller (Blumenau, St. Catharina, Brazil) and he has told me that he believes that in certain plants producing 2 sets of anthers of a different colour, the bees collect the pollen from one of the sets ALONE. He wd. therefore be much interested in your paper, if you have a spare copy that you could send him. I think, but my memory now often fails me, that he has published on the subject in Kosmos.

Hoping that you will excuse me, I remain, Dear Sir Yours faithfully Ch. Darwin

P.S. In my little book on the Fertilization of Orchids, you will find under Mormodes ignea, an account of a flower laterally asymmetrical and what I think that I called right-handed or left-handed flowers. 